\title{
Identifying Sixth Grade Students' Misconceptions on Solar System
}

\author{
Febiola Eka Putri ${ }^{1}$, Neni Hermita ${ }^{*}{ }^{*}$, Zufriady ${ }^{1}$, Tommy Tanu Wijaya ${ }^{2}$ \\ ${ }^{1}$ University of Riau, Pekanbaru, Indonesia \\ ${ }^{2}$ Guangxi Normal University, Guangxi, China \\ *neni.hermita@lecturer.unri.ac.id
}

Abstract

The purpose of this study was to determine sixth grade students' misconception on the solar system. This study uses a sampling technique with a total sample of 88 students. This research uses the descriptive quantitative method. This research aims to describe the misconceptions on the material of the solar system in class 6 of public elementary school in Pekanbaru, data collection techniques using the Four Tier Test. The results showed that students' misconceptions were categorized as "medium" with an average of $47.58 \%$ of 88 students. The highest misconception on material related to the characteristics of stars with a misconception level of $67.61 \%$ with this level can be said that there are still many students who are investigated experiencing misconceptions. The lowest misconception is $27.27 \%$, which is material about the sun as the center of the solar system.

Keywords: diagnostic test; four-tier test; sixth grade students' misconceptions; solar system.

\section{INTRODUCTION}

As stated in Law No. 20 of 2003 concerning the national education system, education is a conscious and planned effort to create an atmosphere of learning and learning process so that students actively develop their potential to have religious-spiritual strength, selfcontrol, personality, intelligence, noble morals as well as the skills needed by himself, society, nation, and state.

Natural science is the science that is carried out with experimental investigations and theoretical explanations of phenomena that occur in the surrounding environment. These phenomena are understood by scientists
In science learning, students have a lot of experience and knowledge related to nature. All students have a lot of experience with motion, force, electricity, magnetism, energy, about living things, inanimate objects, and many other natural events that are known by students before conducting the learning process regardless of whether their knowledge is correct according to "concept" or not. With that experience intuition and "student theory" have been formed about natural events in the everyday environment of humans, but not necessarily intuitions and theories that have been formed are true.

Misconceptions or misconceptions that represent phenomena that are 
present in important discussions in physics and other sciences (Adi \& Oktaviani, 2019; Astuti et al., 2020; N. Hermita et al., 2019, 2017; Parlina et al., 2019), because they are approved can be used in the process of assimilating new knowledge in the minds of students. Misconceptions oppose the inclusion of new ideas or leadership-new scientific revolution, other participants whose misconceptions can reject new ideas or ideas that are accepted, encourage them to find out the attainment of a complete understanding of teaching material (Hermita, 2017). Misconceptions on students should not be allowed and given must be reduced. If misconceptions that occur in elementary students are not immediately reduced, then these misconceptions will carry over until they become students (Hermita, 2017).

The concept is an important thing in teaching and learning activities (Wijaya, Sukma, et al., 2020; Wijaya, Ying, \& Purnama, 2020; Wijaya, Ying, Chotimah, et al., 2020a). teachers must teach concepts properly to prevent misconceptions (Wijaya, Ying, Chotimah, et al., 2020b). Identification of misconceptions in science learning do in the learning process, this process can be done before, before, or before the learning process. This identification requires follow-up activities so students can release from misconception.

Misconception can happen to anyone. Students who like the teacher can also avoid misconceptions. The cause of this misconception is caused by (1) tests or assignments are rarely performed to see misconceptions, (2) misconceptions arise because of analogy errors, (3) many misconceptions arise from questions that are too fast, without being explained, (4) the existence slogans such as 'action equals reaction' and 'every result has a reason', will encourage superficial thinking (Pujayanto, 2011). Based on the background of the problems that have been previously described, the problem formulation in this study is "Are there any misconceptions in the material of the solar system in elementary school?

\section{METHOD}

Based on this, the research carried out research through misconception analysis of Grade VI students of SD Negeri 147 Pekanbaru on solar system material using questions related to the material to be discussed using the Four Tier Test instrument.

The four-tier diagnostic test or fourlevel multiple-choice diagnostic test is a test instrument that functions to reveal misconceptions that occur in students and detect concepts that are already understood and concepts that students do not understand (Wilantika, 2018). The four-tier diagnostic test is a refinement of the three-tier test by adding a level of confidence to the reasons chosen, as seen in Figure for example four-tier questions (Hermita, 2017).

To classify or categorize students in the concept of understanding concepts, not understanding concepts, misconceptions, and errors is done by examining students' answers and matching these answers with table 1 and 
analyzing and categorised based on table

2019).

2 (Sheftyawan, 2018; Marhadi et al.,

Table 1. Design of Four-Tier Test

Question:

Diagnose the state of student conception

Answer Choice (Tier 1):

A. Alternative choice of first answer

B. alternative choice of second answer

C. alternative choice of third answer

D. etc.

The First Confidence Rating Scale (Tier II)

A. Alternative ontion if "sure" over the selected answer

B. Alternative ontion if " not sure" over the selected answer

Reason (Tier III):

A. Alternative choice of first reason

B. alternative choice of second reason

C. alternative choice of third reason

D. Other Reasoning

The Second Rating Scale (Tier IV)

A. alternative choice if convinced of the reasoning answer selected

B. alternative choice if unsure of the chosen reasoning

Table 2. Percentage Rrate of Misconceptions Category

\begin{tabular}{l|l}
\hline Percentage & category \\
\hline $0 \% \leq \mathrm{P}<30 \%$ & low \\
$31 \% \leq \mathrm{P}<60 \%$ & middle \\
$61 \% \leq \mathrm{P}<100 \%$ & high \\
\hline
\end{tabular}

This developmental research produced a valid and reliable question instrument to measure students' misconceptions. The question instrument developed was a question consisting of four levels. The first level is multiplechoice questions, the second level is trust in the choice of answers in multiplechoice, and the third level is the reason for answers to multiple-choice and the fourth level is the student's confidence in the reasons given at level three. The material used is the properties of light. These questions were tested on 88 students (table 3 ). An assessment guide to the answers to questions made by students can be seen in table 4 . 
Table 2. Total Population

\begin{tabular}{llll}
\hline No & Classes & $\begin{array}{l}\text { The number of students per } \\
\text { class }\end{array}$ \\
\hline 1 & VI A & 29 & \\
2 & VI B & 27 & \\
3 & VI C & 32 & \\
\hline Total & & 88 & \\
\hline
\end{tabular}

Table 4. Instrument Grid

\begin{tabular}{|c|c|c|c|}
\hline Variable & Indicator & Sub Indicators & Question number \\
\hline \multirow{5}{*}{ Misconception } & \multirow{5}{*}{$\begin{array}{l}\text { Solar } \\
\text { Systems }\end{array}$} & $\begin{array}{l}\text { The sun is the center of the } \\
\text { solar system }\end{array}$ & 1 \\
\hline & & Star features & 2,4 \\
\hline & & $\begin{array}{l}\text { The characteristics of the } \\
\text { moon }\end{array}$ & 5,12 \\
\hline & & $\begin{array}{l}\text { Planet and its identification } \\
\text { Rotation and revolution }\end{array}$ & $\begin{array}{l}7,10,11,13,14 \\
6,15\end{array}$ \\
\hline & & $\begin{array}{l}\text { Celestial bodies other than } \\
\text { planets and the sun } \\
\text { (Asteroid, Meteor, Comet, } \\
\text { Satelite) }\end{array}$ & $3,8,9$ \\
\hline
\end{tabular}

\section{RESULTS}

The implementation of this research began in October 2019 at SD Negeri 147 Pekanbaru involving 88 students divided into three classes, namely classes VI A and VI B and VI C. This study uses a sampling technique while total sampling is a sampling technique. where the number of samples equals the population. This research uses the descriptive quantitative method. It aims to describe the misconceptions on the material of the solar system in class VI of SD Negeri 147 Pekanbaru, data collection techniques using the Four Tier Test.

The test used in this study is in the form of questions related to the material of the solar system with a 4-level confidence level. For tier 1 , the choice of answers to the questions raised, tier 2, namely the level of confidence in the choice of answers in tier 1 , tier 3, the reasons for tier 1 , and tier 4 , the level of confidence in tier 3 . Before the research instrument was distributed to students, the instrument the test was validated.

The material of the solar system in this study is divided into 6 sub-indicators namely, 1) the Sun as the center of the solar system, 2) the characteristics of the stars, 3) the characteristics of the moon, 4) the planet and its identification, 5) rotation and revolution and 6) objects sky other than planets and sun (Asteroid, Meteor, Comet, Satellite). In processing research data, researchers calculate 
manually by adjusting the decision level to 4 levels (four-tier test).

Data collection in this study was conducted in semester 1 (odd) 2019/2020 school year i.e. starting November 18, 2019-10 December 2019

\section{a. Problems with the level of understanding the concept category}

Based on data from research tests that have been conducted, it can be seen the percentage of students who understand the concept in each subindicator in figure

1.

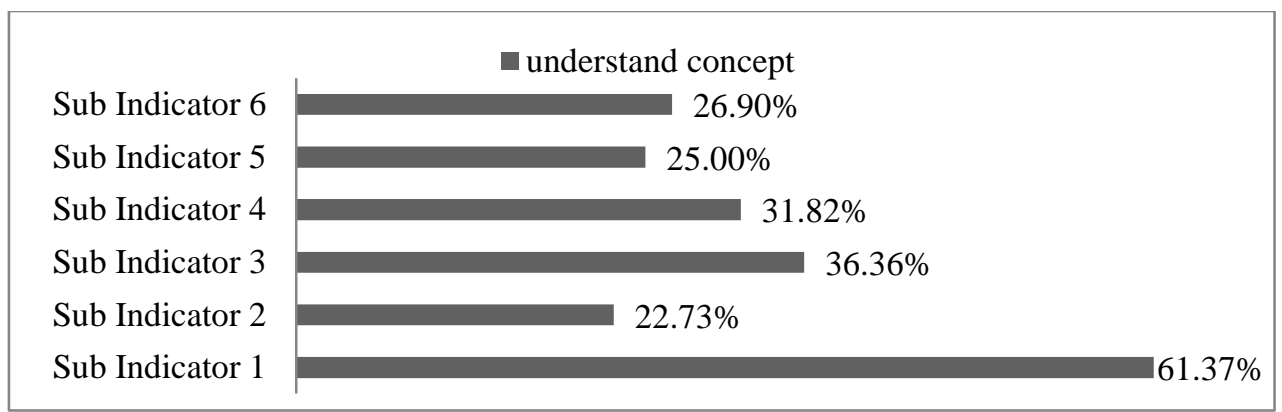

Figure 1. Students' Conception Profile on Medium Category

can be seen the level of understanding of the concept of students in the category of "medium" with an average of $31.29 \%$ of 88 students. Sub indicator 1 (the sun as the center of the solar system) with a percentage of $61.37 \%$ of 88 students who understand the concept, this is categorized as "high". In sub-indicator 2 (star traits) with a percentage of conceptual understanding of $22.73 \%$ of 88 students categorized as "medium". Sub Indicator 3 (characteristics of the month) with the percentage of students understanding the concept of $36.36 \%$ of 88 students categorized as "high". Sub indicator 4 (planet identification) students have a conceptual understanding of $31.82 \%$ of 88 students who fall into the "medium" category. Sub indicator 5 (rotation and revolution) students have a concept of $25.00 \%$ of 88 students and enter the "low" category. And finally on subindicator 6 (Celestial bodies other than planets and the sun (Asteroids, Meteors, Comet, Satellites)) students have a concept of $26.90 \%$ of 88 students and enter the "low" category. This proves that understanding the concept of grade VI students at SD Negeri 37 Pekanbaru on the material of the solar system is still not quite high.

\section{b. Problems with category level do not understand the concept}

From the results of grouping the results of student answers, we get a percentage of not understanding the concepts contained in each item according to the graph. 


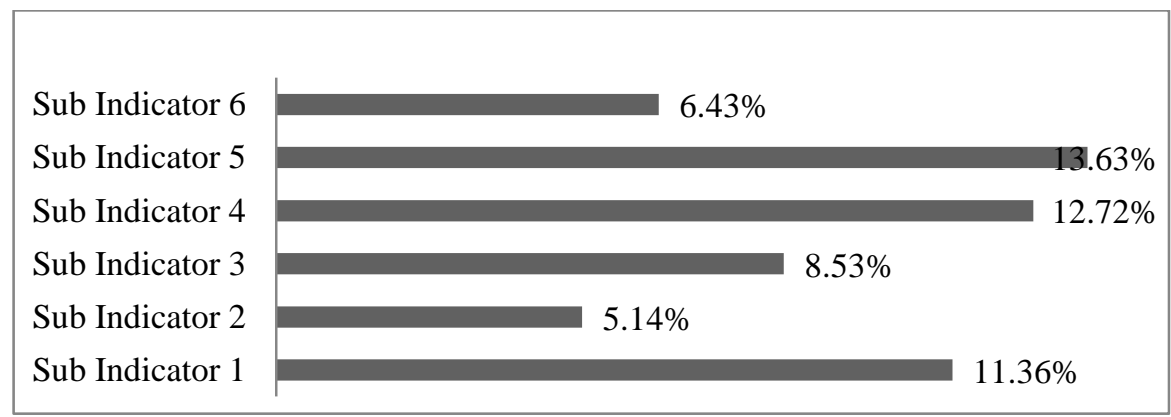

Figure 2 Students' Conception Profile on Low Category

Based on figure 2, it can be seen that the level of not understanding students' concepts is categorized as "low" with an average of $9.93 \%$ of 88 students. Not understanding the highest concept lies in Sub Indicator 5 with a percentage of $13.63 \%$. Sub indicator 1 (the sun as the center of the solar system) with a percentage of $11.36 \%$ of 88 students who do not understand the concept, is categorized as "low". In sub-indicator 2 (the characteristics of stars) with a percentage of not understanding the concept of $5.14 \%$ of 88 students categorized as "low". Sub Indicator 3 (characteristics of the month) with the percentage of students not understanding the concept of $8.53 \%$ of 88 students categorized as "low". Sub indicator 4 (planet identification) students have not understood the concept of $12.72 \%$ of 88 students who fall into the "low" category. Sub indicator 5 (rotation and revolution) students do not understand the concept of $13.63 \%$ of 88 students and fall into the "low" category. And finally on sub-indicator 6 (Celestial bodies other than planets and the sun (Asteroids, Meteors, Comet, Satellites) students have not understood the concept of $6.43 \%$ of 88 students and enter the "low" category. This proves that not understanding the concept of grade VI students of SD Negeri 147 Pekanbaru in the matter of the solar system is still relatively low.

\section{c. Problems with the level of misconception}

From figure 3 we can see that students' misconceptions are categorized as "medium" with an average of $47.58 \%$ of 88 students. Sub indicator 1 (the sun as the center of the solar system) with a percentage of $27.27 \%$ of 88 students who misconceptions, this is categorized as "low". In sub-indicator 2 (star characteristics) with a percentage of misconceptions of $67.61 \%$ of 88 students categorized as "high". Sub Indicator 3 (characteristics of the month) with the percentage of students' misconceptions of $46.59 \%$ of 88 students categorized as "medium". Sub indicator 4 (planet identification) students experience misconceptions of $45.23 \%$ of the 88 students who fall into the "medium" category. Sub indicator 5 (rotation and revolution) students experience misconceptions of $46.02 \%$ of 88 students 
and fall into the "medium" category. And finally in sub-indicator 6 (Celestial bodies other than planets and the sun (Asteroids, Meteors, Comet, Satellites) students experience misconceptions of $46.59 \%$ of 88 students and fall into the "medium" category. This proves that there are still many VI-grade students of SD Negeri 147 Pekanbaru who experience misconceptions about the solar system material being tested.

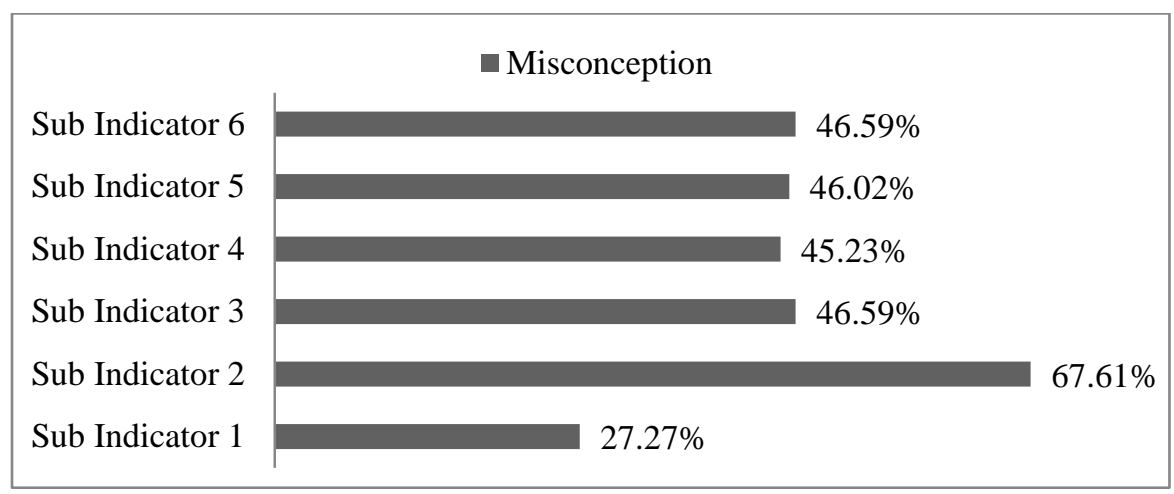

Figure 3 Students' Conception Profile on Misconception Category

\section{d. Problems with error category levels}

can be seen that the level of student error is categorized as "low" with an average of $11.20 \%$ of 88 students. Sub indicator 1 (the sun as the center of the solar system) with a percentage of $0 \%$ of 88 students who error, this is categorized as "low". In sub-indicator 2 (the characteristics of stars) with $4.52 \%$ of 88 students, the error percentage is categorized as "low". Sub Indicator 3 (characteristics of the month) with a percentage of student error of $8.52 \%$ of 88 students categorized as "low". Sub indicator 4 (planet identification) students experienced an error of $10.23 \%$ of the 88 students included in the "low" category. Sub indicator 5 (rotation and revolution) students experience an error of $15.34 \%$ of 88 students and enter the "low" category. Finally, in sub-indicator 6 (Celestial bodies other than planets and the sun (Asteroids, Meteors, Comet, Satellite)) students experienced an error of $20.08 \%$ of 88 students and entered the "low" category. This proves that the grade VI students of SD Negeri 37 Pekanbaru on the material of the solar system experienced low errors. 


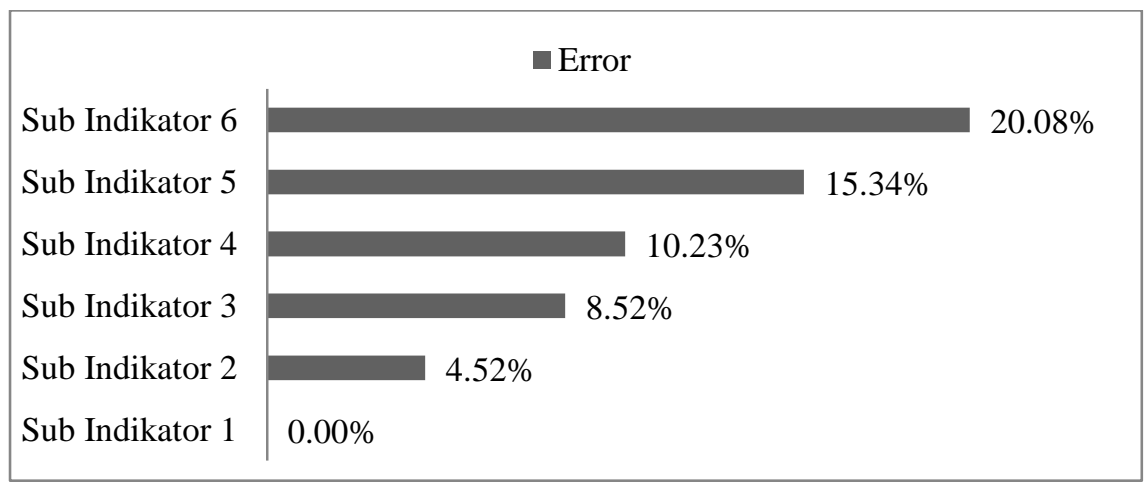

Figure 4 Students' Conception Profile on Error Category

\section{DISCUSSION}

The causes of misconceptions include the use of teaching methods. Teaching methods that only contain lectures and writing, do not reveal misconceptions, narrow demonstration models and nonmultiple intelligence are the main causes of misconceptions (Soeparno, 2013). So that the ability of the teacher to use the learning method in the form of a lecture as found in the field is a factor in the high misconceptions on material related to the solar system. This condition can cause children to easily forget the material they are learning so that what is experienced in everyday life causes students to experience the wrong (context) about the material of the solar system. Another factor that causes students to experience misconceptions is also due to the ability of the students themselves, for example, students pay less attention to the teacher when explained about the subject matter.

Students' mistakes in understanding the material caused by student experience (context) are a form of humanistic thinking in which the thinking is thought that views all objects from a human perspective. The behavior of objects is understood as the behavior of living things, so it is not suitable (Nurulwati, 2014). Conditions can occur because the level of understanding of students is still at a concrete stage and this also occurs because students do not get explanations from people around them to explain the true thing.

One of the efforts to overcome misconceptions is by remedying misconceptions through remedial teaching activities. One of the remedial teaching modes that can be used is text mode, and to remediate misconceptions, conceptual change text or CCText can be used. Conceptual change text (CCText) is a type of text that is deliberately developed for remedial teaching-oriented to remediation of misconceptions experienced by students (Hermita, 2017).

Overcoming misconceptions requires learners to be aware of misunderstandings and be dissatisfied with them and substitute concepts to become available understandable, sensible, and valid learning cycles identify misunderstandings in the early 
stages of learning and teachers can easily stop teaching and then redirect concepts (N. Hermita et al., 2020; Neni Hermita et al., 2020; ). The learning cycle teaching approach prevents misunderstanding in three ways; understanding of concepts, improved problem solving, better laboratory skills, and also technological tools help eliminate misconceptions (Turkmen, 2007).

\section{CONCLUSION}

Based on the results and discussion of the research, it can be concluded that the misconceptions of grade VI SD

\section{REFERENCES}

Adi, Y. C., Oktaviani, N. M. (2019). Miskonsepsi Siswa SD pada Materi Physical Processes: Sebuah Studi Kasus. Tunjuk Ajar: Jurnal Penelitian IImu Pendidikan, 2(1), 1-14.

Astuti, D., Anggraeni, L., \& Setyawan, F. (2020). Mathematical probability: Student's misconception in higher education. Journal of Physics: Conference Series, 1613(1). https://doi.org/10.1088/17426596/1613/1/012009

Anggari, A. S., et al. (2015). Exploring Outer Space. Jakarta: Ministry of Education and Culture.

Astuti, F., et al. (2016). Identification of Misconceptions and Their Causes in Class XI MIA Students of SMA Negeri 1 Sukoharjo in the 2015/2016 Academic Year on Stoichiometry Main Material. Journal of Chemical

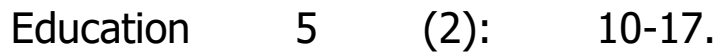

students on the material of the solar system are still quite high. The highest misconception category was material related to star characteristics with a conceptual understanding of $67.61 \%$ and the lowest was material regarding the sun as the center of the solar system with a misconception of $22.27 \%$. The highest level of student misconception for each item was item number 4 , the sub-indicator of star characteristics, which received a percentage value of $64.77 \%$ while the lowest level of student misconception was in item number 1 the indicator of the sun as the center of the solar system with a percentage $27.27 \%$.

https://jurnal.fkip.uns.ac.id/index.php /kimia/article/view/7888

Faizah, K. (2016). Misconceptions in Science Learning. Darussalam Journal: Journal of Education, Communication and Islamic Law Thought 8 (1): $115-128$. Downloaded from https://ejournal.iaida.ac.id/index.php /darussalam/article/download/10/8

Hermita, N., et al. (2017). Constructing and Implementing a Four Tier Test about Static Electricity to Diagnose Pre-service Elementary School Teachers' Misconceptions. Journal of Physics: Conference Series 895: 1-6. Downloaded from https://iopscience.iop.org/article/10.1 088/1742-6596/895/1/012167

Hermita, N., Alpusari, M., Noviana, E., Kurniaman, O., Widyanthi, A., \& Suhandi, A. (2019). A Study of Prospective Primary School 
Teachers' Alternatif Conception in Heat and Temperature. Journal of Physics: Conference Series, 1351(1). https://doi.org/10.1088/17426596/1351/1/012072

Hermita, N, Ningsih, H. S., Alim, J. A., Alpusari, M., Putra, Z. H., \& Wijaya, T. T. (2020). Developing Science Comics for Elementary School Students on Animal Diversity. Solid State Technology, 63(1s).

Hermita, N., Alpusari, M., Noviana, E., Kurniaman, O., Widyanthi, A., \& Suhandi, A. (2019). A Study of Prospective Primary School Teachers' Alternatif Conception in Heat and Temperature. Journal of Physics: Conference Series, 1351(1). https://doi.org/10.1088/17426596/1351/1/012072

Hermita, N., Alpusari, M., Noviana, E., Putra, Z. H., Islami, N., Basori, H., Suhandi, A., \& Samsudin, A. (2020). Improving prospective primary school teachers' mental models through implementation of CdOI supported by multimode visualization. Universal Journal of Educational Research, 8(2). https://doi.org/10.13189/ujer.2020.0 80217

Hermita, N., Suhandi, A., Syaodih, E., Samsudin, A., Isjoni, Johan, $H_{\text {., }}$ Rosa, F., Setyaningsih, R., Sapriadil, \& Safitri, D. (2017). Constructing and Implementing a Four Tier Test about Static Electricity to Diagnose Pre-service Elementary School Teacher' Misconceptions. Journal of Physics: Conference Series, 895(1). https://doi.org/10.1088/17426596/895/1/012167

Hermita, N, Ningsih, H. S., Alim, J. A., Alpusari, M., Putra, Z. H., \& Wijaya, T. T. (2020). Developing Science Comics for Elementary School Students on Animal Diversity. Solid State Technology, 63(1s).

Ibda, F. (2015). Cognitive Development: Jean Piaget's Theory. Journal of Intellectuals 3 (1): 27-38. Downloaded from https://jurnal.arraniry.ac.id/index.php/intel/article/do wnload/197/178

Marhadi, H., Lazim, L., Hermita, N., Alpusari, M., Widyanthi, A., Suhandi, A., Sutarno, S., Mahbubah, K., \& Samsudin, A. (2019). Implementing a four-tier diagnostic test to assess elementary school students' on electricity magnetism concept. Journal of Physics: Conference Series, 1157(3), 032020.

Nurulwati. A. V. \& Ruslan, M. A. (2014). An Overview of the Types and Causes of Physical Misconceptions. Indonesian Journal of Science Education 2 (1): 87-95. Downloaded from

http://www.jurnal.unsyiah.ac.id/JPSI/ article/view/7636

Ormrod, J. E. (2008). Educational psychology helps students grow and develop Volume I. Jakarta: Erlangga.

Parlina, T. A., Hermita, N., Alpusari, M., \& Noviana, E. (2019). Identifying Pupils' Mental Model of the Day and Night Concept. Journal of Teaching and Learning in Elementary Education 
https://doi.org/10.33578/jtlee.v2i2.7 573

Pujayanto, P. (2011). Misconceptions of Science (Physics) in Elementary School Teachers. Journal of Materials and Learning Physics (JMPF) 1 (1): 22. Retrieved from http://jurnal.fkip.uns.ac.id./index/php /fisika/article/view/1856. https://doi.org/10.1088/1742$6596 / 1157 / 3 / 032020$

Rahardjo, M. (2018). Between concepts, propositions, theories, variables, and hypotheses in research. Downloaded from malang.ac.id/2410/

http://repository.uin-

Samatowa, U. (2011). Natural Science Learning in Primary Schools. jakarta: index.

Sheftyawan, W. B., et al. (2018). Identification of Student Misconceptions Using a Four-Tier Diagnostic Test on Optical Geometry Material. Journal of Learning Physics 7 (2): 147-153. Downloaded from https://jurnal.unej.ac.id/index.php/JP F/article/download/7921/5577/

Sugiyono, S. (2015). Educational Research Methods Approach Quantitative, Qualitative, And R \& D. Bandung: Alfabeta.

Supangat, A. (2010). Statistics in Inference and Nonparametric Descriptive Studies. Jakarta: Kencana Prenada Media Group

Suparno, P. (2013). Misconceptions and changing concepts in physics education. Jakarta: Grasindo.

Turkmen, H. (2007). The Role Of Learning Cycle Ap. Roach Overcoming
Misconceptions In Science. Kastamonu Egitim Dergisi, No: 2. Wijaya, T. T., Sukma, M., Purnama, A., \& Tanuwijaya, $\mathrm{H}$. (2020). Pengembangan media pembelajaran berbasis tpack menggunakan hawgent dynamic mathematics software. Journal of Elementary Education, 03(03), 64-72.

Wijaya, T. T., Ying, Z., Chotimah, S., Bernard, M., Zulfah, \& Astuti. (2020a). Hawgent dynamic mathematic software as mathematics learning media for teaching quadratic functions. Journal of Physics: Conference Series, 1592(1). https://doi.org/10.1088/17426596/1592/1/012079

Wijaya, T. T., Ying, Z., Chotimah, S., Bernard, M., Zulfah, Z., \& Astuti, A. (2020b). Hawgent dynamic mathematic software as mathematics learning media for teaching quadratic functions. Journal of Physics: Conference Series, 1592(1).

https://doi.org/10.1088/17426596/1592/1/012079

Wijaya, T. T., Ying, Z., \& Purnama, A. (2020). Using Hawgent dynamic mathematics software in teaching trigonometry. International Journal of Emerging Technologies in Learning, 15(10). https://doi.org/10.3991/ijet.v15i10.1 3099

Wijaya, T. T., Sukma, M., Purnama, A., \& Tanuwijaya, H. (2020). Pengembangan media 
pembelajaran berbasis tpack menggunakan hawgent dynamic mathematics software. Journal of Elementary Education, 03(03), 6472.

Wijaya, T. T., Ying, Z., Chotimah, S., Bernard, M., Zulfah, \& Astuti. (2020a). Hawgent dynamic mathematic software as mathematics learning media for teaching quadratic functions. Journal of Physics: Conference Series, 1592(1). https://doi.org/10.1088/17426596/1592/1/012079

Wijaya, T. T., Ying, Z., Chotimah, S., Bernard, M., Zulfah, Z., \& Astuti, A. (2020b). Hawgent dynamic mathematic software as mathematics learning media for teaching quadratic functions. Journal of Physics: Conference Series, 1592(1). https://doi.org/10.1088/1742$6596 / 1592 / 1 / 012079$

Wijaya, T. T., Ying, Z., \& Purnama, A. (2020). Using Hawgent dynamic mathematics software in teaching trigonometry. International Journal of Emerging Technologies in Learning, 15(10). https://doi.org/10.3991/ijet.v15i10.13 $\underline{099}$ 